\title{
MOLECULAR DOCKING STUDY ON THE BINDING MODE OF CARDIOSELECTIVE PHENOXYAMINOPROPANOL BLOCKER INTO B-ADRENERGIC RECEPTOR SUBTYPES
}

\author{
Polakovičová, M. - Čižmáriková, $R$. \\ Comenius University in Bratislava, Faculty of Pharmacy, \\ Department of Chemical Theory of Drugs
}

\begin{abstract}
Structural understanding of subtype specific ligand-binding pocket variations and interactions of ligand with receptor may facilitate design of novel selective drugs. To gain insights into the subtype selectivity of $\beta$-blockers we performed flexible molecular docking study to analyze the interaction mode of cardioselective phenoxyaminopropanol blocker into the $\beta_{1}$ and $\beta_{2}$-adrenergic receptor. The binding site analysis reveals a strong identity between important amino acid residues and interactions with ligand in orthosteric catecholamine- binding pocket. The differences in the binding mode of selective ligand have been identified in the extracellular region of receptor subtypes.
\end{abstract}

Keywords: $\beta$-adrenergic receptor - $\beta$-blockers - selectivity - molecular docking extracellular loops

\section{INTRODUCTION}

G-protein-coupled receptors (GPCRs) constitute the largest family of integral membrane proteins mediating a variety of physiological and pathophysiological processes with almost 900 members. It has been estimated that one-third of all pharmaceuticals used today act through GPCRs (Heilker et al., 2009). GPCRs also known as seven transmembrane receptors, share a common molecular architecture consisting of seven transmembrane helix bundle linked by three intracellular and three extracellular loops with intracellular $\mathrm{C}$ terminus and extracellular $\mathrm{N}$ terminus (Topiol et al., 2009).

GPCRs are an integral part of the plasmatic membrane and their crystallization and structural evaluation is somewhat problematic due to their inherent instability and conformational mobility. The first successfully solved GPCR 3D-structure was bovine rhodopsin reported in year 2000 (Okada et al., 2000). Over the last decade, the number 
of GPCRs crystals has increased remarkably and until today crystal structures of $\beta_{1}$ adrenergic receptor $\left(\beta_{1}\right.$-AR) and $\beta_{2}$-adrenergic receptor $\left(\beta_{2}-\mathrm{AR}\right), \mathrm{A}_{2 \mathrm{~A}}$ adenosine, $C X C R_{4}$ chemokine, $\mathrm{D}_{3}$ dopamine, $\mathrm{H}_{1}$ histamine, $\mathrm{M}_{2}$ and $\mathrm{M}_{3}$ muscarine, $\mathrm{S}_{1} \mathrm{P}_{1}$ spingosine, $\mu, \kappa$, and $\delta$-opioid receptors are available (Jacobson et al., 2012). Nevertheless, the vast majority of GPCR structures and their ligand complexes are still unsolved, and no structures are known outside A subfamily of GPCRs.

The $\beta_{1}$-AR and $\beta_{2}$-AR belong to a few GPCRs whose 3D-structure has been solved even for their structural subtypes, and high-resolution picture of ligand-binding pockets provides opportunities to the rational receptor-based development of subtype-selective ligands (Rasmussen et al., 2007; Warne et al., 2008).

Antagonists and inverse agonists of $\beta$-adrenergic receptors ( $\beta$-ARs), $\beta$-blockers, are widely prescribed drugs for the treatment of many cardiovascular diseases or indications of such problems. $\beta$-ARs could be divided into 3 subtypes: $\beta_{1}$-ARs, $\beta_{2}$-ARs and $\beta_{3}$-ARs. The therapeutic activity of $\beta$-blockers is attributed to the blockage of $\beta_{1}$-ARs predominantly expressed in cardiac tissue. $\beta_{2}$-ARs are present mainly in the smooth muscle of the peripheral circulation and bronchi. The third subtype $\beta_{3}$-AR is predominantly located in adipose tissue and plays a role in regulating the gastrointestinal tract and bladder smooth muscle (Hieble, 2000).

An important difference between clinically used $\beta$-blockers is their selectivity for the $\beta_{1}$ and $\beta_{2}$-AR subtypes. However, this selectivity is only relative and dose dependent and the search for compounds that selectively inhibit activity of individual receptor subtype is an important aim in medicinal chemistry (Baker et al., 2011).

Extensive mutational analysis and crystal structures of $\beta_{1}$-ARs have established the most important amino acid residues of transmembrane helix 3 (TM3), transmembrane helix 5 (TM5), transmembrane helix 6 (TM6) and transmembrane helix 7 (TM7) involved in receptor activation or blockage that form the orthosteric ligandbinding site. Some of these receptor interactions are common for agonists and antagonists alike, while the others are specific for agonists only. The main structural change of orthosteric binding site after agonist binding, is the contraction of ligandbinding pocket about $1 \AA$ and rotamer conformational changes of $\operatorname{Ser}^{5.45}$ and $\operatorname{Ser}^{5.46}$ relative to the antagonist bound receptor (Warne et al., 2011). Throughout this paper the uppercase numbering of amino acids is based on the unique Ballesteros-Weinstein nomenclature of sequence A subfamily GPCRs based on the position of the residue relative to the most conserved position in specific TM helix (Ballesteros \& Weinstein, 1995). To distinguish numbering in $\beta_{1}$-AR and $\beta_{2}$-AR, the absolute number of the residue in sequence of particular receptor subtype is written by standard Arabic numerals. The anchoring and the most important interaction in $\beta$-ARs is polar interaction between carboxyl group of $\mathrm{Asp}^{3.32}$ on TM3 and propanolamine nitrogen of ligand found in all amine receptors (Horn et al., 1998). A strong polar interaction network between the catechol functional group formed by serines $\mathrm{Ser}^{5.42} \mathrm{Ser}^{5.43}$ and Ser $^{5.46}$ on TM5 is specific for agonists only. Interactions between the receptor and ligands that position aryl moiety adjacent to $\mathrm{Phe}^{6.51}$, $\mathrm{Phe}^{6.52}$ and $\operatorname{Trp}^{6.48}$ are common for both agonist and antagonist binding mode.

The ligand-binding pocket comprises of 15 amino acid residues in 4 transmembrane helices and extracellular loop 2 (ECL2). This loop forms the entrance of the ligand binding pocket and is stabilized by two disulphide bonds and a sodium ion. The binding 
of inverse agonists and antagonists in $\beta_{1}$-AR and $\beta_{2}$-AR involves the same interaction pattern. In orthosteric-binding site structure of $\beta_{1}$-AR, there are 15 amino acid residues when using a $4 \AA$ distance criterion for which the side chains make contacts with ligands: $\mathrm{Tyr}^{5.38}, \mathrm{Ala}^{5.39}, \mathrm{Ser}^{5.42}, \mathrm{Ser}^{5.43}, \mathrm{Ser}^{5.46}, \mathrm{Val}^{3.33}, \mathrm{Phe}^{5.32}, \mathrm{Phe}^{6.51}, \mathrm{Phe}^{6.52}$, $\operatorname{Trp}^{6.48}, \mathrm{Asn}^{7.39}, \mathrm{Val}^{3.36}, \mathrm{Asp}^{3.32}, \operatorname{Trp}^{3.28}, \mathrm{Tyr}^{7.43}$. All of these residues are identical to those in human $\beta_{2}$-AR (Warne et al., 2011).

Until now none of the reported $\beta$-AR crystal receptor complexes possess selective ligand binding. To explain why some ligands preferentially bind to either $\beta_{1^{-}}$AR or $\beta_{2^{-}}$ $\mathrm{AR}$, the knowledge of differences in amino acid residues close to the ligand-binding pocket that could affect ligand binding is necessary.

The purpose of our laboratory research is focused to the development of novel selective $\beta$-blockers of aryloxyaminopropanol type. The position pattern of substituent, such as ortho-/meta-/para-, frequently leads to a significant effect on the chemical behavior and even to the biological action of a compound based on its efficacy, toxicity and selectivity. Substitution in the para-position relative to the oxyaminopropanol chain of phenoxyaminopropanol based drugs, such as metoprolol, bisoprolol, betaxolol, atenolol, practolol, modulates the efficacy of these compounds to the higher $\beta_{1^{-}}$selectivity. In the past years a large set of ortho and para-substituted $\beta$-AR blockers has been synthesized and biologically examined, among which 1-\{3-(propoxymethyl)-4-[2hydroxy-3-\{3,4-dimethoxyphenethylamino $\}$ propoxy]phenyl $\}$ propane-1-one (PHEP) (Figure 1) with excellent selectivity ratio $\beta_{1} / \beta_{2}=977$ was identified (Čižmáriková et al., 2003).<smiles>CCCOCc1cc(C(=O)CC)ccc1OCC(O)CNCCc1ccc(OC)c(OC)c1</smiles>

Figure 1 Structure of docked selective ligand 1-\{3-(propoxymethyl)-4-[2-hydroxy3-\{3,4-dimethoxyphenethylamino\}propoxy]phenyl\}propane-1-one (PHEP)

To gain insights into subtype specific ligand-receptor interactions and selective binding mode of PHEP, we performed molecular docking study on $\beta_{1}$-AR and $\beta_{2}$-AR. Molecular docking methods explore possible orientations of ligand into the protein and analyze binding poses of the ligand in ligand-receptor complex taking into account the computed binding energy values (Shoichet et al., 2002).

The final poses of docked selective ligand in the $\beta_{1}$-AR and $\beta_{2}$-AR are compared with the poses of co-crystallized nonselective ligand carazolol (Figure 2), and different amino acid interactions are discussed. 
<smiles>CC(C)NCC(O)COc1cccc2[nH]c3ccccc3c12</smiles>

Figure 2 Structure of nonselective carazolol, co-crystallized ligand in both receptor complexes of $\beta_{1}-A R$ ( $p d b$ code: $2 Y C W$ ) and $\beta_{2}-A R$ (pdb code:2RH1)

\section{COMPUTATIONAL DETAILS}

All calculations were performed on Lenovo ThinkStation S20 computer and Sybyl-X1.3 molecular modeling package in evaluation version (Sybyl, 2011).

The ligand structure was built in sketch module using standard geometric parameters and optimized by AM1 method with gradient $0.01 \mathrm{kcal} /(\mathrm{mol} \AA)$. The Flexidock method implemented in Sybyl-X1.3 was used for molecular docking. Flexidock scores all the positions and calculates the binding energy with van der Waals, electrostatic, torsion, Hbonding and constraint energy terms of Tripos force field and generates top 20 conformations. The binding pockets of $\beta_{1}$-AR and $\beta_{2}$-AR were defined to cover all residues within $4 \AA$ of the co-crystallized ligand. All single bonds of amino acid residue side chains inside the binding pocket were defined as flexible. The docked ligand was allowed to rotate on all of the single bonds.

After the crystallographic water molecules were removed and hydrogen atoms added, appropriate atomic charges were recalculated using Kollman all-atomic parameterization for the proteins and AM1 charges for the ligand. Amine nitrogen of aminopropanol chain of ligand was considered as protonated assuming ionic interaction with carboxyl group of Asp121/113 ${ }^{3.32}$. The docked ligand PHEP was prepositioned in the ligand binding cavity using the original position of co-crystallized carazolol as a template for the starting position for Flexidock search. Default Flexidock parameters with maximum number of 60000 generations were set. Finally, docked receptor-ligand complexes were energy-minimized by using Powell minimization with a gradient of $0.01 \mathrm{kcal} /(\mathrm{mol} \AA)$ and 10000 cycles to remove potential bad clashes. From the resulting receptor-PHEP complex of $\beta_{1}$-AR and $\beta_{2}$-AR those docked structures were selected that possess crucial interaction of ligand with $\mathrm{Asp}^{3.32}$ and achieved the highest docking score.

\section{RESULTS AND DISCUSSION}

Flexible ligand docking was performed with Flexidock method that uses a genetic algorithm to probe conformational space by defining possible interactions between the ligand and its putative binding site. The X-ray crystallographic structures $2 \mathrm{YCW}$ of $\beta_{1^{-}}$ $\mathrm{AR}$ and $2 \mathrm{RH} 1$ of $\beta_{2}-\mathrm{AR}$, both with carazolol as co-crystallized ligand deposited 
in Protein database were used in the docking experiments. In order to validate the accuracy of the proposed receptor-ligand structure, Flexidock was performed to check the binding mode of co-crystallized carazolol. Carazolol was extracted from the binding pocket and subsequently docked into its original pocket. The Flexidock program was able to match the ligand-protein geometry and hydrogen bonding pattern seen in the crystal for both the $\beta_{1}$-AR and $\beta_{2}$-AR subtypes with RMSD values of 0.5069 and 0.5350 Å respectively.

The ligand-binding pocket of $\beta$-ARs forms a narrow deep cleft that is largely concealed from solvent (Figure 3). As the orthosteric ligand-binding site has the same spatial and amino acid structure for $\beta_{1}$-AR and $\beta_{2}$-AR, the resulting position of docked PHEP also is very similar in both receptor subtypes.

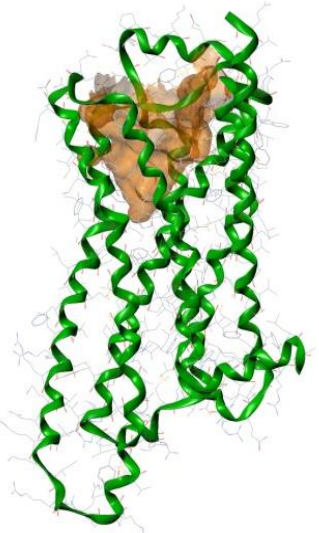

Figure 3 3D-crystallographic structure of $\beta_{1}-A R$ (pdb code:2YCW) with highlighted green backbone and orange colored ligand binding pocket

The binding energies $E_{\text {bind }}$ of final binding poses of docked carazolol and PHEP in $\beta_{1}$ $\mathrm{AR}$ and $\beta_{2}$-AR with experimental $\mathrm{pA}_{2}$ values (Borchard, 1998; (Čižmáriková et al., 2003) are presented in Table 1.

Table 1. Molecular docking $\mathbf{E}_{\text {bind }}$ and experimental $\mathbf{p A}_{2}$ values of carazolol and PHEP ligands in $\beta$-AR subtypes.

\begin{tabular}{cccccc}
\hline & $\mathrm{E}_{\text {bind }} / \beta_{1}-\mathrm{AR}$ & $\mathrm{E}_{\text {bind }} / \beta_{2^{-}} \mathrm{AR}$ & $\mathrm{pA}_{2} / \beta_{1^{-}}$ & $\mathrm{pA}_{2} / \beta_{2^{-}}$ & selectivity \\
& {$[\mathrm{kJ} / \mathrm{mol}]$} & {$[\mathrm{kJ} / \mathrm{mol}]$} & $\mathrm{AR}$ & $\mathrm{AR}$ & \\
\hline carazolol & -919.2 & -921.6 & $9.9^{*}$ & $9.4^{*}$ & $0.4^{*}$ \\
PHEP & -708.5 & -690.2 & $7.8 \pm$ & $4.81 \pm$ & $977^{\#}$ \\
& & & $0.28^{\#}$ & $0.19^{\#}$ & \\
\hline
\end{tabular}

$\mathrm{E}_{\text {bind }}$ - calculated Flexidock molecular docking energy of binding, $\mathrm{pA}_{2}$-antiisoprenaline activity,

* (Čižmáriková et al., 2003), \# (Borchard, 1998) 
Although used molecular mechanics scoring function calculates only the relative energy of ligand binding, it can be seen that $\mathrm{E}_{\text {bind }}$ values correlate well with the experimental affinities expressed as antiisoprenaline $\mathrm{pA}_{2}$ values.

The molecular docking proposed binding pose of PHEP in the orthosteric catecholamine-binding pocket of both $\beta_{1}$-AR and $\beta_{2}$-AR exhibits the same general mode of binding observed for other $\beta$-AR blockers (Warne et al., 2012). Aminopropanol nitrogen and hydroxyl group form polar bonds with $\mathrm{Asp}^{3.32}$ and $\mathrm{Asn}^{7.39}$. Oxygen of propanoyl group interacts with $\mathrm{Ser}^{5.43}$. The phenyl group is stabilized by strong hydrophobic interaction with $\mathrm{Phe}^{5.62}$ and $\mathrm{Phe}^{5.63}$. Terminal methyl of the propanoyl group is involved in hydrophobic interaction with $\mathrm{Val}^{3.36}$.

Compared to nonselective co-crystallized carazolol, PHEP possess bulky aromatic substituent -dimethoxyphenylethyl group on aminopropanol nitrogen and propoxymethyl chain in the neighboring position (Figure 1).

These substituents make additional contacts in the extended ligand binding pocket in the nonconserved region of extracellular loop 2 (ECL2) and extracellular loop 3 (ECL3) (Figure 4).

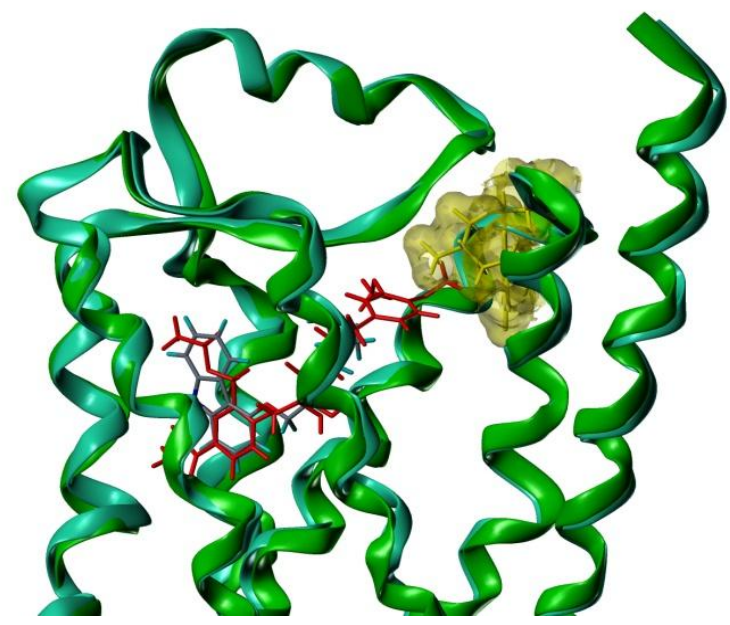

Figure 4 Superimposed structures of crystallographic complex of carazolol (blue) in $\beta_{1}$-AR (pdb code:2YCW) and docked complex of PHEP (red) in $\beta_{1}$-AR (pdb code:2YCW). Selective PHEP penetrates higher in the extracellular region comparing to nonselective carazolol and provides additional interactions with amino acids of extracellular loop ECL3 highlighted in yellow spherical models

The propoxymethyl chain participates in additional hydrophobic interactions with Ala208/2005.39 and Phe307/290 6.52 that are still inside the orthosteric catecholamine-binding pocket. (First number assigns number of the specific amino acid residue in $\beta_{1}$-AR, and the second the number in the sequence of $\beta_{2}$-AR.) Different amino acid interactions compared to nonselective blockers reach selective PHEP by dimethoxyphenyl substituent penetrating higher in the extracellular region. 
The dimethoxyphenyl ring is stabilized by hydrophobic interaction with Trp117/109.28 and $\operatorname{Trp} 107 / 99^{2.70}$ in $\beta_{1}$-AR and $\beta_{2}$-AR. The most important selective interaction seems to be the interaction of one of the phenylmethoxy group with Leu101 2.64 in $\beta_{1}$-AR. In this position in $\beta_{2}$-AR is polar His93 $3^{2.64}$. The hydrophobic cleft formed by Trp107, Leu101, Trp117 in $\beta_{1}$-AR should be stronger, interacting with dimethoxyphenyl group of PHEP than lesser hydrophobic cluster Trp99, His93, Trp109 in $\beta_{2}$-AR (Figure 5).
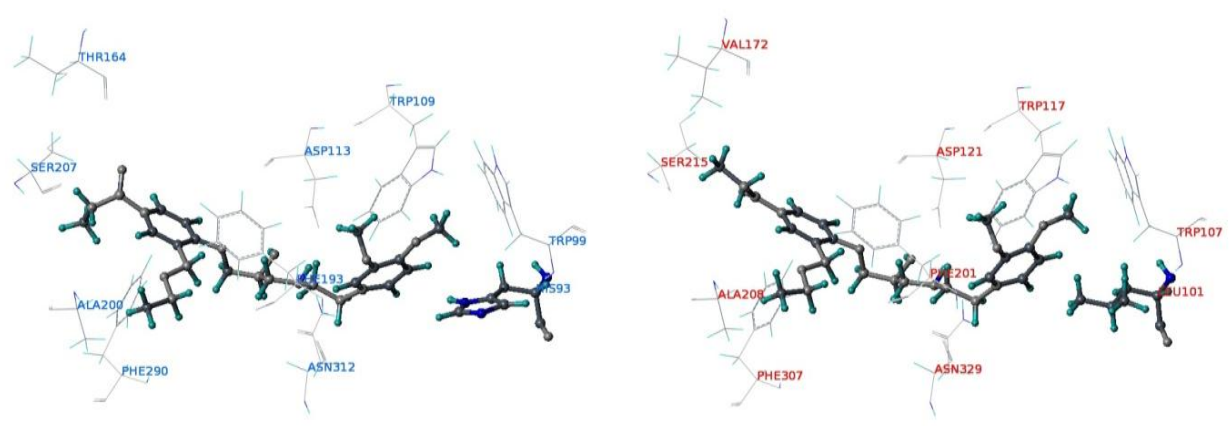

Figure 5 Ligand binding pockets of docked PHEP in $\beta_{1}-A R$ (right) and in $\beta_{2}-A R$ (left). Amino acids in $\beta_{1}-A R$ are red labeled, in $\beta_{2}$-AR are blue labeled. Structures of PHEP and amino acid differing the selective binding mode in position 3.04 by Ballesteros-Weinstein nomenclature (LEU101/HIS93) are depicted by ball-and-stick models.

Thus stabilization of noncontracted extended binding pocket in $\beta_{1}$-AR by selective PHEP could be more efficient in $\beta_{1}$-AR than in $\beta_{2}$-AR. The $\operatorname{Trp}^{2.70}$ - Leu/His ${ }^{2.64}-\operatorname{Trp}^{3.28}$ hydrophobic cluster is in close proximity to the disulphide bridge highly conserved among A subfamily GPCRs connecting the anti-parallel $\beta$-sheet in ECL2 with the top of TM3 and stabilizing the rigidity of the entrance of receptor (Fig. 4). The ECL2 and ECL3 can contribute to the specificity of ligand binding by directly forming part of extended ligand-binding cavity (Peeters et al., 2011). Similar phenomenon was observed in studies on ligand selectivity in adenosine $\mathrm{A}_{2 \mathrm{~A}}$ receptor where long sidechain of the selective receptor antagonist protrudes out of the transmembrane region into the extracellular area (Jaakola et al., 2010). Interactions with nonconserved extracellular region as the determinant of ligand selectivity have been confirmed also for muscarinic receptor ligands (Johannes et al., 2009).

\section{CONCLUSION}

High resolution $3 \mathrm{D}$-structure of $\beta_{1}$-AR and $\beta_{2}$-AR represents important template for virtual screening of selective GPCR ligands. We performed molecular docking study of highly selective $\beta$-blocker into the $\beta_{1}$-AR and $\beta_{2}$-AR. Studied cardioselective ligand provides additional interactions with the extended ligand-binding pocket of the receptor compared to nonselective co-crystallized ligands. The obtained results unveil that it is 
possible to discriminate among the binding modes of $\beta$-AR subtypes by specifying different amino acid interactions of selective ligand in the extracellular region. Outcomes of our study are consistent with reported results for adenosine and muscarinic GPCRs.

\section{REFERENCES}

Baker JG, Hill SJ, Summers RJ. Evolution of $\beta$-blockers: from anti-anginal drugs to ligand-directed signalling. Trends Pharmacol Sci. 2011;32:227-234.

Ballesteros JA, Weinstein $\mathrm{H}$. Integrated methods for the construction of threedimensional models and computational probing of structure-function relationship in Gprotein coupled receptors. Methods Neurosci. 1995;23:366-428

Borchard U. Pharmacological properties of $\beta$-adrenoceptor blocking drugs. J Clin Bas Cadiol. 1998;1:5-9.

Čižmáriková R, Račanská E, Hroboňová K, Lehotay J, Ághová Y, Halešová D. Synthesis and pharmacological activity and chromatographic separation of novel potential $\beta$-blockers of the aryloxyaminopropanol type. Pharmazie. 2003;58:237-241.

Heilker R, Wolff M, Tautermann ChS, Bieler M. G-protein-coupled receptor-focused drug discovery using a target class platform approach. Drug Discov Today. 2009;14:231-240.

Hieble JP. Adrenoceptors subclassification: an approach to improved cardiovascular therapeutics. Pharmacochem Lib. 2000;31:163-171.

Horn F, Weare J, Beukers MW, et al. GPCRDB: an information system for G proteincoupled receptors. Nucleic Acids Res. 1998;26:275-279.

Jaakola VP, IjzermanAP. The crystallographic structure of the adenosine A2A receptor in high-affinity antagonist-bound state: implication for GPCR drug screening and design. Curr Opinion Struct Biol. 2010;20:401-414.

Jacobson KA, Constanzi S. New insights for drug design from the X-ray crystallographic structure of G-protein-coupled receptors. Mol Pharmacol. 2012;82:361371.

Johannes A, Kellershohn K, Mohr-Adra M, et al. Dualsteric GPCR targeting: a novel route to binding and signaling pathway selectivity. FASEB. 2009;23:442-450.

Okada T, Le Trong I, Fox BA, Behnke CA, Stenkamp RE, Palczewski K. X-ray diffraction analysis of three-dimensional crystals of bovine rhodopsin obtained from mixed micelles. J Struct Biol. 2000;130:73-80. 
Peeters MC, van Westen GJP, Li Q, IJzerman AP. Importance of the extracellular loops in $\mathrm{G}$ protein-coupled receptors for ligand recognition and activation. Trends Pharmacol Sci. 2011;32:35-42.

Rasmussen S, Choi H, Rosenbaum D, et al. Crystal structure of the human $\beta 2$ adrenergic G-protein-coupled receptor. Nature. 2007;450:383-387.

Shoichet BK, McGovern SL, Wei B, Itwin J. Lead discovery using molecular docking. Curr Opinion Chem Biol. 2002;6:439-446.

Sybyl. Molecular Modeling Software Package, Tripos mc., St. Louis MO 63144 USA, 2011.

Topiol S, Sabio M. X-ray structure breakthroughs in the GPCR transmembrane region. Biochem Pharmacol. 2009;78:11-20.

Warne T, Serrano-Vega M, Baker J, et al. Structure of a $\beta 1$ adrenergic G-proteincoupled receptor. Nature. 2008;454:486-491.

Warne T, Moukhametzianov R, Baker JG, et al. The structural basis for agonist and partial agonist action on a $\beta 1$-adrenergic receptor. Nature. 2011;469:241-244.

Warne T, Edwards PC, Leslie AGW, Tate C. Crystal structures of stabilized $\beta 1$ adrenoceptor bound to the biased agonists bucindolol and carvedilol. Structure. 2012;20:841-849.

Registered: October 4, 2012

Accepted: November 8, 2012
RNDr. Mária Polakovičová, CSc.

Comenius University in Bratislava

Faculty of Pharmacy

Odbojárov 10

83232 Bratislava

Slovak Republic

polakovicova@fpharm.uniba.sk 


\title{
ŠTÚDIUM VÄZBOVÉHO MÓDU KARDIOSELEKTÍVNEHO BLOKÁTORA FENOXYAMINOPROPANOLOVÉHO TYPU V PODTYPOCH B-ADRENERGNÉHO RECEPTORA METÓDOU MOLEKULOVÉHO KOTVENIA
}

\begin{abstract}
Polakovičová, M. - Čižmáriková, $R$.
Univerzita Komenského v Bratislave, Farmaceutická fakulta, Katedra chemickej teórie liečiv

Porozumenie štruktúrnym variáciám podtypovo-špecifických ligandviažucich miest a interakcií ligandu s receptorom môže ul'ahčit' návrh nových selektívnych liečiv. Na bližší náhl'ad na podtypovú selektivitu $\beta$-blokátorov a analýzu interakčného väzbového módu kardioselektívneho blokátora $\mathrm{v} \beta_{1}$ a $\beta_{2}$-adrenergnom receptore sme použili metódu flexibilného molekulového kotvenia. Analýza väzbového miesta preukázala identitu dôležitých aminokyselinových reziduí a interakcií ligandu v ortostérickom mieste katecholového priestoru. Rozdiely vo väzbovom móde selektívneho ligandu boli identifikované v mimobunkovom priestore jednotlivých podtypov receptora.
\end{abstract}

Acta Fac. Pharm. Univ. Comen. LIX, 2012, (2), p. 44-53. 